\title{
Adherence to antiretroviral therapy and correlation with adverse effects and coinfections in people living with HIV/AIDS in the municipality of Goiás State
}

\author{
Luane da Silva Oliveira ${ }^{[1]}$, Lorena Maria Caixeta ${ }^{[1]}$, José Luís Rodrigues Martins ${ }^{[1]}$, \\ Kelly Deyse Segati ${ }^{[1]}$, Rodrigo Scaliante Moura ${ }^{[1]}$, Marcelo Cecílio Daher ${ }^{[1]}$ \\ and Emerith Mayra Hungria Pinto ${ }^{[1]}$
}

[1]. Centro Universitário de Anápolis, UniEVANGÉLICA, Anápolis, GO, Brasil.

\begin{abstract}
Introduction: Acquired immunodeficiency syndrome is an advanced stage of a human immunodeficiency virus infection. The antiretroviral therapy aims to improve the life quality of HIV patients and a good adherence is essential for a better prognosis. This study aimed to evaluate the adherence of human immunodeficiency virus/acquired immunodeficiency syndrome patients to antiretroviral therapy recommended by the Brazilian health system in Anápolis/Goiás, and correlate the level of adherence with sociodemographic data and clinical-laboratory variables. Methods: Adherence to antiretroviral therapy was assessed using the Questionnaire for Evaluation of Adherence to Antiretroviral Therapy. The sociodemographic data were collected using a standardized questionnaire and the clinical-laboratory records were reviewed. Results: Among 220 patients included, 59\% (129/220) were men and the average age was 41 years. Infection was acquired primarily through sexual contact $(92 \%, 202 / 220)$, and $69 \%(152 / 220)$ of the patients were heterosexual. Approximately $86 \%(188 / 220)$ of the patients had good or strict adherence to antiretroviral therapy. In our study, the use of illicit drugs was associated with low adherence to antiretroviral therapy $(\mathrm{p}=0.0004)$, and no significant association was observed between adherence levels and other sociodemographic data $(\mathrm{p}>0.05)$. The logistic regression indicated that adverse effects $(\mathrm{p}=0.0018)$ and sexual orientation $(\mathrm{p}=0.0152)$ were associated with the level of adherence to antiretroviral therapy. Patients with good or strict adherence had higher CD4+T lymphocyte count $(\mathrm{p}<0.0001)$ and undetectable viral load $(\mathrm{p}<0.0001)$. Patients with low adherence $(14 \%, 32 / 220)$ had higher frequency of adverse events $(\mathrm{p}=0.0009)$. The frequency of coinfections was $25 \%(55 / 220)$, with syphilis and tuberculosis being the most common coinfections. Conclusions: Adherence was related to use of illicit drugs, adverse effects, and sexual orientation.
\end{abstract}

Keywords: HIV.AIDS. ART adherence. Coinfections. Adverse effects.

\section{INTRODUCTION}

HIV infection can be transmitted through unprotected sex, contact with contaminated blood, and maternal-fetal transmission ${ }^{1}$.The natural course of HIV infection is characterized by acute viral syndrome with rapid lymphocyte (LTCD4+) depletion and inability of the immune system to eradicate the virus $^{2}$. Subsequently, the clinical latency period was developed, which can last from 2 to 10 years or more. During clinical latency, HIV continues to replicate at low levels, causing gradual loss of LTCD4 $+^{2}$. The immunological depletion caused by the virus contributes to the development of severe opportunistic infections such as tuberculosis, pneumonia, hepatitis, toxoplasmosis, and cytomegalovirus, as well as the appearance

Corresponding author: $\mathrm{Dr}^{\mathrm{a}}$ Emerith Mayra Hungria Pinto.

e-mail:emerith0706@hotmail.com; emerith.pinto@docente.unievangelica.edu.br Received 2 February 2018

Accepted 4 July 2018 of secondary neoplasms and neurological manifestations, the most advanced stage of the disease, called AIDS ${ }^{2-5}$.

According to the World Health Organization (WHO), 35 million people are living with HIV-1 and about 2 million new infections are reported each year. From 2007 to June 2016, about 136,945 new cases were registered in Brazil. In 2015, 2,574 cases of HIV infection were reported in the Midwest region $^{6}$. In the Goiás State, between the years 2014 and 2015, 1,017 new cases were reported in the municipality of Anápolis ${ }^{7}$.

Combined antiretroviral (ARV) regimens developed in the late 1990s were proven effective in suppressing viral replication and have changed the natural course of the disease. Worldwide, an estimated 10 million people infected with HIV are receiving antiretroviral therapy (ART) ${ }^{8}$. The major classes of ARV drugs are as follows: 1) nucleoside and nucleotide reverse transcriptase (RT) inhibitors (NRTIs), 2) non-nucleoside TR inhibitors (NNRTIs), 3) inhibitors of protease (PI), 4) integrase inhibitors (IINs), and 5) inhibitors of entry (IE) ${ }^{9}$. In Brazil, initial ART regimens are composed of two classes of ARVs, NRTIs 
associated with NNRTIs or NRTIs associated with IINs ${ }^{10}$. At the time of data collection (September 2016 to February 2017), the initial preferential scheme recommended in the Clinical Protocol and Guidelines Therapy for Management of HIV Infection in Adults [Protocolo Clínico e Diretrizes Terapêuticas (PCDT) para Manejo da Infecção pelo HIV emAdultos] of the Ministry of Health [Ministério da Saúde(MS)] was composed of lamivudine (3TC), tenofovir (TDF), and efavirenz (EFV) ${ }^{10}$. In February 2017, the initial preferential scheme for adults was updated as follows: 3TC + TDF + dolutegravir (DTG).

Undoubtedly, the fact that ART does not represent cure has transformed HIV infection from a progressive and fatal disease into a chronic infection, prolonging and promoting a better life quality for patients. Studies showed that non-adherence occurs, to some degree, in developed and underdeveloped countries ${ }^{10-14}$. Non-adherence and inadequate adherence are the most frequent causes of treatment failure because the use of drugs in inadequate or irregular doses accelerates the process of selection of resistant viral strains, threatening the effectiveness of the treatment at the individual level and leading to the dissemination of resistant viruses in the collective plane ${ }^{8,15}$.

Studies have shown that the appearance of adverse effects is a risk factor for non-adherence ${ }^{12,13,16,17}$. ARV treatment may lead to conditions associated with the development of cardiovascular events, such as dyslipidemia, diabetes, lipodystrophy, systemic arterial hypertension, insulin resistance, and glucose intolerance. In addition, it can lead to conditions such as nephropathies, thromboembolic phenomena, hematological toxicity, gastrointestinal toxicity, hepatotoxicity, cutaneous hypersensitivity, neuropsychiatric effects, peripheral neuropathy, altered bone metabolism, ascending neuromuscular weakness syndrome, and mitochondrial toxicity, among others ${ }^{18}$. Therefore, ART can contribute to the occurrence of numerous health problems, with consequences for both the patient and the health system, as it interferes with adherence to treatment, changes prescription patterns, and causes increased costs with specialized assistance and hospitalizations. In this sense, studies that allow a better understanding of the phenomenon, investigating the influence of sociodemographic, clinical, and laboratory variables, are fundamental to the development of intervention strategies favoring a better adherence to $\mathrm{ART}^{19}$.

Although the policy of universal and free access to ARVs in Brazil is internationally recognized, there was still shortage of published studies that evaluate the effectiveness of the strategies implemented to guarantee adequate adherence to treatment or to improve them, as well as to identify populations with greater fragility in adherence to treatment ${ }^{1,19,20}$. This study aimed to evaluate the level of adherence to ART in patients with human immunodeficiency virus/acquired immunodeficiency syndrome (HIV/AIDS) and to correlate the level of adherence with the sociodemographic data, clinical-laboratory data, and development of adverse effects and confections.

\section{METHODS}

This is a cross-sectional study carried out in the Dr. Ilion Fleury Jr. outpatient clinic, a reference unit for diagnosis and treatment of sexually transmitted infections (STIs) in the City of Anápolis, Goiás State [370,875 inhabitants/Instituto Brasileiro de Geografia e Estatística (IBGE) 2016]. A sample calculation was performed in 1,017 patients who underwent follow-up based on the frequency of low adherence to antiretroviral therapy of $20 \%$, with an accuracy of $5 \%$ and confidence level of $95 \%$, resulting in a final sample of 220 patients (OpenEpi Program version 3).The patients were randomly selected from among those who attended the unit to receive ART from September 2016 to February 2017.

Individuals with HIV/AIDS using ART and those who had a 6-month follow-up at the unit, those aged $>18$ years, and both sexes were included in the study. Sociodemographic data were collected using a semistructured standardized questionnaire containing information about sex, age, and schooling; municipality of residence; monthly income; and marital status. Evaluation of adherence to ART was performed using the Questionnaire for the Evaluation of Adherence to Antiretroviral Therapy (CEAT-VIH), validated in Brazil by Remor et al. ${ }^{21}$. The Brazilian version proved to be reliable for application in the Portuguese language to assess internal consistency, validity related to external criteria, sensitivity, and specificity.

The clinical records of the study participants were reviewed to obtain information on the likely category of exposure, date of HIV diagnosis, history of opportunistic diseases in the last 12 months, and laboratory results regarding TCD4+ lymphocyte count and viral load. Data confidentiality and anonymity of all research participants were guaranteed.

Descriptive analysis, including calculation of average, median, standard deviation, and percentages, was performed in Microsoft Office Excel ${ }^{\circledR}$ to describe adherence levels. A chi-square test was used to assess the independent variables such as sociodemographic and clinical-laboratory data of HIV patients in relation to adherence to ART. Data were considered statistically significant when the $p$ value was $\leq 0.05$.

The logistic regression analysis was performed to verify which clinical and socioeconomic variables were maintained in relation to the variable adherence to ART. An $\alpha$ level of significance (5\%) was used, the variable adherence was used as variable response, and the other factors as explanatory variables. As the model aimed to describe the behavior of all variables in relation to the level of adherence, all the observations present in the dataset were used in this logistic regression. Adherence was assessed on only two levels, good or strict. The good variable was constructed by joining the low and good levels of the adherence variable and kept the strict level. The statistical system R was used for the analysis.

\section{Ethical considerations}

Patients who agreed to participate in the study signed a free and informed consent form, which described information regarding the objectives of the study and methodology, following the principles recommended by the National Health Council, through resolution 466/12. This study was approved by the Research Ethics Committee of the University Center of Anápolis-UniEVANGÉLICA (protocol number: 1,676,182). 


\section{RESULTS}

\section{Characteristics of study population}

Among $220 \mathrm{HIV} /$ AIDS patients included in the study, 59\% $(n=129)$ were men and the average age was 41 years (range: 19 -77 years). In terms of educational level, only $39 \%(n=86)$ of the participants had a high school education, and 49\% (107/220) received a minimum wage. About $92 \%$ of the participants $(202 / 220)$ declared that sexual transmission was the probable route of infection and 69\% (152/220) declared themselves heterosexual. Table 1 describes the sociodemographic data of the study group.

With regard to the clinical-laboratory data, the time of HIV diagnosis was 6.9 years (range: $0.5-30$ years) and $51 \%(111 / 220)$ of the patients reported a diagnosis of HIV less than five years. Approximately 65\% (142/220) of the patients had a CD4+ T lymphocyte count of greater than 500 cells $/ \mathrm{mm}^{3}$, while $52 \%$ $(114 / 220)$ had an undetectable viral load.

\section{Evaluation of ART adherence and adverse effects}

Results of the evaluation of adherence to ART using CEATVIH indicated that $50 \%(109 / 220)$ of the patients presented good adherence, $36 \%(79 / 220)$ presented strict adherence, and 14\% $(32 / 220)$ presented low adherence. Table 2 shows the correlation among sociodemographic data, clinical-laboratory data, and adherence to ART. Among sociodemographic variables, the use of illicit substances was the only factor associated with low adherence $(\mathrm{p}=0.0004)$, and no significant difference was observed between other sociodemographic characteristics and adherence to ART.

The majority of patients included in the study $(79 \%$, $175 / 220)$ used 1 to 4 tablets daily, 20\% (43/220) used 5 to 8 tablets/day, and 1\% (2/220) used more than 9 tablets/day; no significant difference was observed between the number of tablets ingested daily and adherence to ART $(\mathrm{p}=0.1164)$.

Regarding laboratory variables, we observed an association between CD4+ T lymphocyte count and adherence to ART;

TABLE 1: Sociodemographic characteristics of people living with HIVIAIDS treated at a reference center in Anápolis, Goiás, Brazil, from September 2016 to February $201(n=220)$.

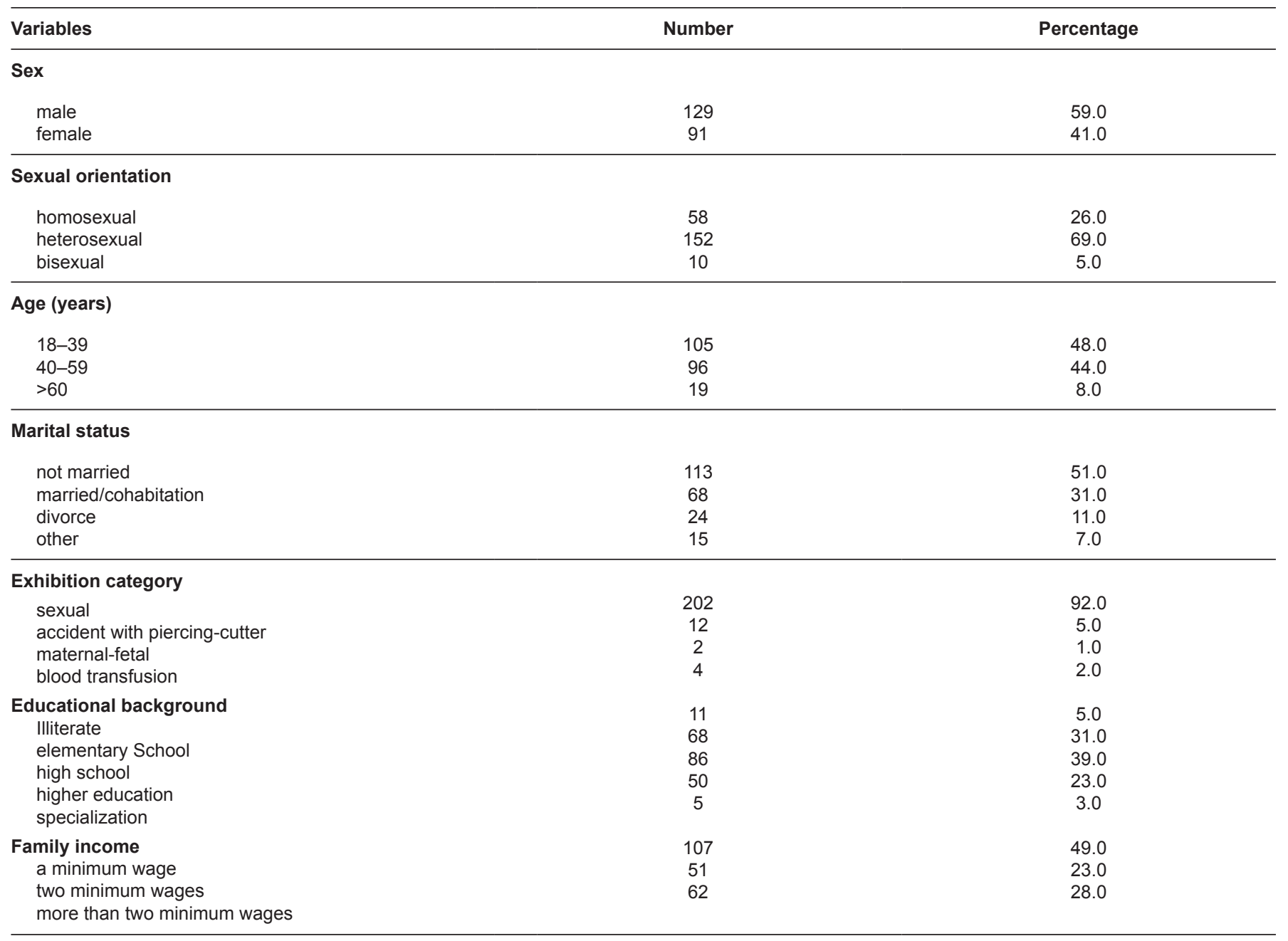

HIVIAIDS: human immunodeficiency virus/acquired immunodeficiency syndrome. 
TABLE 2: Association between sociodemographic, clinical, and laboratory variables and adherence to ART, according to the Questionnaire for the Evaluation of Adherence Therapy, Anápolis, Goiás, Brazil, from September 2016 to February 2017 ( $n=220)$.

\begin{tabular}{|c|c|c|c|c|c|c|c|c|c|}
\hline & \multicolumn{9}{|c|}{ Classification of the level of adherence to ART } \\
\hline & \multicolumn{2}{|c|}{$\operatorname{low}(n=32)$} & \multicolumn{2}{|c|}{$\operatorname{good}(n=109)$} & \multicolumn{2}{|c|}{ strict(n=79) } & \multicolumn{2}{|c|}{ total $(n=220)$} & \multirow[t]{2}{*}{$\mathbf{p}$} \\
\hline & $\mathbf{n}$ & $\%$ & $\mathbf{n}$ & $\%$ & $\mathbf{n}$ & $\%$ & $\mathbf{n}$ & $\%$ & \\
\hline female & 14 & 15.0 & 19 & 54.0 & 28 & 31.0 & 91 & 100.0 & 0.1024 \\
\hline male & 18 & 14.0 & 60 & 46.0 & 51 & 40.0 & 129 & 100.0 & \\
\hline $18 \mid-39$ & 14 & 13.0 & 53 & 51.0 & 38 & 36.0 & 105 & 100.0 & 0.3428 \\
\hline $40|-| 59$ & 15 & 16.0 & 43 & 45.0 & 38 & 39.0 & 96 & 100.0 & \\
\hline$>60$ & 3 & 16.0 & 13 & 68.0 & 3 & 16.0 & 19 & 100.0 & \\
\hline \multicolumn{10}{|l|}{ Sexual orientation } \\
\hline heterosexual & 24 & 16.0 & 82 & 54.0 & 46 & 30.0 & 152 & 100.0 & 0.0859 \\
\hline homosexual & 6 & 10.0 & 24 & 42.0 & 28 & 48.0 & 58 & 100.0 & \\
\hline \multicolumn{10}{|l|}{ Viral load (copies/ml) } \\
\hline undetectable & 7 & 6.0 & 67 & 59.0 & 40 & 35.0 & 114 & 100.0 & $<0.0001$ \\
\hline$<500$ & 13 & 16.0 & 35 & 43.0 & 33 & 41.0 & 81 & 100.0 & \\
\hline$>500$ & 12 & 48.0 & 7 & 28.0 & 6 & 24.0 & 25 & 100.0 & \\
\hline \multicolumn{10}{|l|}{ HIV diagnosis time } \\
\hline$<5$ & 14 & 12.0 & 54 & 49.0 & 43 & 39.0 & 111 & 100.0 & 0.3588 \\
\hline $5|-| 10$ & 9 & 18.0 & 20 & 41.0 & 20 & 41.0 & 49 & 100.0 & \\
\hline$>10$ & 9 & 15.0 & 35 & 58.0 & 16 & 27.0 & 60 & 100.0 & \\
\hline \multicolumn{10}{|l|}{ Alcohol consumption } \\
\hline yes & 15 & 16.0 & 46 & 50.0 & 31 & 34.0 & 92 & 100.0 & 0.7366 \\
\hline not intense & 14 & 10.0 & 68 & 49.0 & 57 & 41.0 & 139 & 100.0 & \\
\hline \multicolumn{10}{|l|}{ Number of tablets/day } \\
\hline $1-4$ & 22 & 13.0 & 88 & 50.0 & 65 & 37.0 & 175 & 100.0 & 0.1164 \\
\hline $5-8$ & 10 & 23.0 & 21 & 49.0 & 12 & 28.0 & 43 & 100.0 & \\
\hline $9-12$ & -- & 0.0 & -- & 0.0 & 2 & 100.0 & 2 & 100.0 & \\
\hline \multicolumn{10}{|c|}{ Combination of drugs } \\
\hline $\mathrm{TDF}+3 \mathrm{TC}+\mathrm{EFV}$ & 11 & 11.0 & 50 & 50.0 & 39 & 39.0 & 100 & 100.0 & 0.3643 \\
\hline others & 21 & 18.0 & 59 & 49.0 & 40 & 33.0 & 120 & 100.0 & \\
\hline \multicolumn{10}{|l|}{ Coinfections } \\
\hline yes & 7 & 13.0 & 28 & 51.0 & 20 & 36.0 & 55 & 100.0 & 0.939 \\
\hline no & 25 & 15.0 & 81 & 49.0 & 59 & 36.0 & 165 & 100.0 & \\
\hline
\end{tabular}

ART: antiretroviral therapy; LTCD4+: CD4 + T lymphocyte; HIV: human immunodeficiency virus; TDF: tenofovir; 3TC: lamivudina; EFV: efavirenz.

higher counts were observed in the groups with good/strict adherence to ART compared with the group with low adherence $(\mathrm{p}<0.0001)$. Viral load was also associated with the level of adherence. Undetectable or lower viral load was observed in the groups with good/strict adherence compared with the group with low adherence to ART $(\mathrm{p}<0.0001)$. The association of CD4 + T lymphocytes count, viral load, and adherence to ART is detailed in Table 3.

The most commonly prescribed drug combination was 2 NRTI + 1 NRTI (TDF + 3TC + EFV), and the second most common was 2 ITRN + 1 IP (TDF + 3TC + atazanavir/ritonavir $(\mathrm{ATV} / \mathrm{r}))$. Results showed that these variables are statistically 


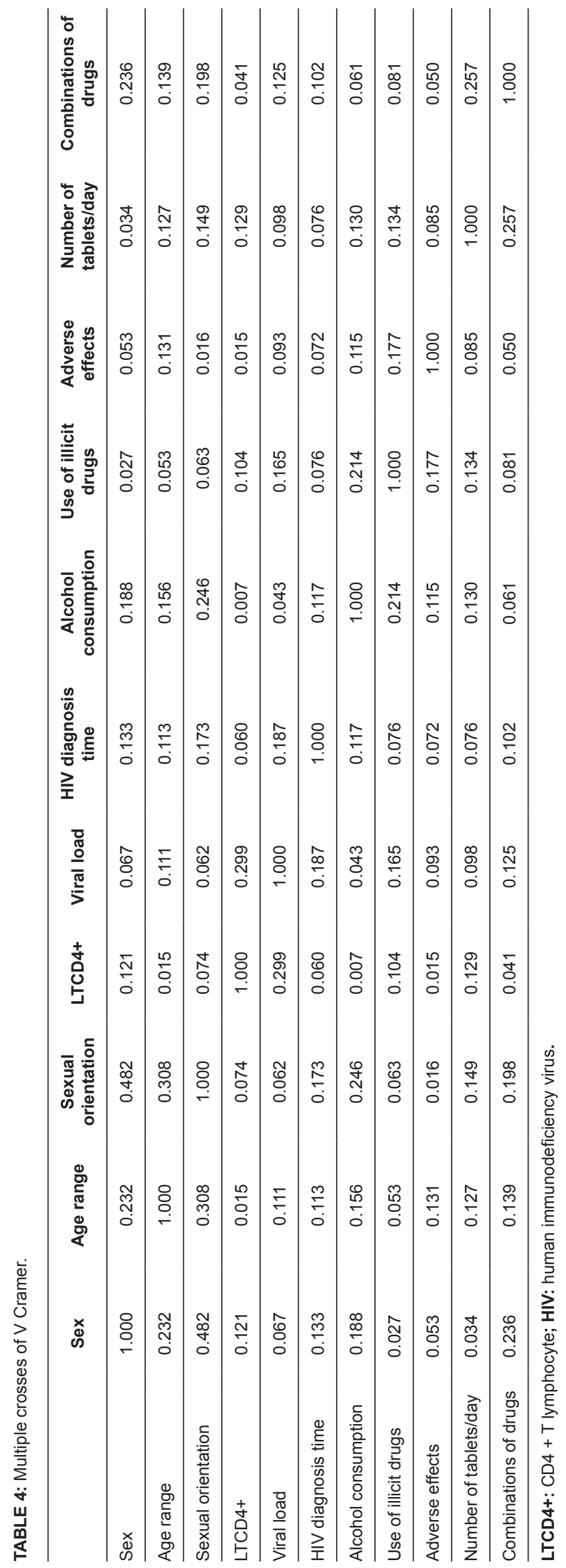

HPV $(2.27 \%, 5 / 220)$, hepatitis B $(0.9 \%, 2 / 220)$, hepatitis C $(0.45 \%, 1 / 220)$, and leprosy $(0.45 \%, 1 / 220)$. Some patients had multiple coinfections such as syphilis + hepatitis B $(0.9 \%$, $2 / 220)$, cytomegalovirus + syphilis + herpes zoster $(0.45 \%$, $1 / 220)$, hepatitis C + HPV $(0.45 \%, 1 / 220)$, hepatitis C + neurotoxoplasmosis $(0.45 \%, 1 / 220)$, and syphilis + hepatitis $\mathrm{C}(0.45 \%, 1 / 220)$.

The level of adherence was not associated with the presence or absence of coinfections $(\mathrm{p}=0.939)$. When we verified the level of adherence to ART in coinfected patients $(n=55)$, their adherence to HAART were also assessed in three levels: $36 \%$ $(\mathrm{n}=20)$ had strict adherence, $51 \%(\mathrm{n}=28)$ had good adherence, and $13 \%(n=7)$ had low adherence.

\section{Logistic regression}

In the final logistic model, adverse effects $(\mathrm{p}=0.0018)$ and sexual orientation $(\mathrm{p}=0.0152)$ were the only variables associated with the level of adherence to ART. In the same way, when we evaluated the data using the matrix of V Cramer, results showed that adverse effects and sexual orientation had the greatest association with adherence to ART (Table 4).

\section{DISCUSSION}

This is the first study to describe the level of adherence to ART in the municipality of Anápolis, the third largest municipality in the State of Goiás (370,875 inhabitants/2016). Adherence is a major issue in the management of chronic diseases; for people living with HIV/AIDS, the use of ART at prescribed doses and frequencies guarantees great benefits, such as reduction in the occurrence of opportunistic diseases, reduction in the frequency of hospital admissions, reduction in mortality rates, and consequent increase in the time and treatment life quality ${ }^{19-22}$. Our results indicated that $85 \%$ $(188 / 220)$ of the participants had good or strict adherence to ART and, considering the entire sample, 85\% (77/91) of women and $86 \%(111 / 129)$ of men presented good or strict adherence to ART. These results were discordant compared with those of another study that used CEAT-HIV in the State of Ceará, which presented adherence rates of $14 \%$ and $48.7 \%{ }^{20}$. This difference can be explained by changes in lifestyle, access to quality treatment, and early diagnosis, since the studies were carried out in different regions of Brazil.

In our study, the use of illicit drugs was associated with low adherence to ART ( $\mathrm{p}=0.0004)$. Use of illicit drugs negatively influenced the individual's decision regarding therapy and compromised adherence ${ }^{23,24}$. Previous studies indicated that illicit drug users with HIV present delayed onset of follow-up or inadequate use of health service, constituting an important reason for the delay in initiating follow-up for HIV infection, late initiation of ART use, and therefore low adherence to ART ${ }^{25}$. Moreover, the shared risk factors increased the likelihood of HIV-infected individuals who use drugs to become coinfected with viral hepatitis or tuberculosis that facilitates disease progression, overlapping drug toxicities, drug-drug interactions, and side effects ${ }^{26}$. Reduction in HIV-related morbidity and mortality is less pronounced among HIV-infected individuals who use illicit drugs; therefore, strategies aimed at improving 
adherence in this group of patients are a challenge for health services. Some interventions are recommended to improve viral suppression among HIV-infected individuals who use drugs, including directly administered ART, opioid substitution therapy like methadone or buprenorphine to opioid-dependent patients, and integration of HIV and addiction services ${ }^{27}$.

Other sociodemographic characteristics had no influence on the degree of adherence to ART. The socioeconomic level is not considered to be a good predictor of the level of adherence to treatment, except in situations of extreme poverty ${ }^{21,28}$, since such condition may imply difficulty in accessing treatment. Majority of the evaluated individuals were men (59\%, 129/220). Although the number of male patients was higher, this difference was small, reflecting the epidemiological trend of the disease growth in women, due to the increase in heterosexual HIV transmission ${ }^{29}$. In our study, heterosexual patients were at risk for lower adherence to treatment. A study conducted in Rio de Janeiro in 2013 also showed that participants who identified themselves as heterosexual were more likely to report missing pills than those who identified themselves as homosexual/gay ${ }^{30}$. A previous study reported that HIV-infected heterosexual men who are having difficulty adhering to ART are more likely to engage in risky sexual behaviors and therefore benefit from counseling about these risk behaviors ${ }^{31}$.

The most prevalent age group was 18 to 39 years old ( $48 \%$, $105 / 220$ ), with an average age of 41 years. A similar study found that increasing age is statistically linked to adherence ${ }^{32}$; however, we did not find this relationship in our study. The treatment time was not a consensus variable in the literature in relation to a greater prediction of adherence. Patients who received treatment for a short period of time are more likely to not adhere to treatment than those who have been treated for a longer time. This can be justified by the fact that patients become more committed to following the treatment when they perceive gains in their clinical condition, depending on the medications ${ }^{33}$.

The laboratory variables, CD4 + T lymphocyte count $(p<0.0001)$ and viral load $(p<0.0001)$, were associated with $\mathrm{good} /$ strict adherence to ART. Viral load is a biological marker that should always be evaluated, since the goal of ART is the suppression of viral load, seeking to preserve the immune function. The CD4 + T lymphocyte count provides the direct measurement of a patient's immune status and remains as the best way to quantify the degree of immunosuppression and associated risk of AIDS illnesses. However, WHO recently suggested that in situations where viral load is available and patients experience virological suppresssion, $\mathrm{CD} 4+$ monitoring presents little value and stopping CD4+ lymphocyte count monitoring will have major cost savings. Several studies showed a statistically significant relationship between viral load and CD4+ T lymphocyte counts and adherence level ${ }^{8,14,28}$.

The occurrence of adverse effects was described in $10 \%$ of the studied population, and it is possible to correlate the appearance of adverse effects with low adherence to ART ${ }^{14,16,32}$. Adverse effects start rapidly, usually within the second week after the beginning of the treatment, and are mild and temporary in most cases. However, data suggested $2 \%-6 \%$ of patients discontinue treatment because of severe or prolonged effects ${ }^{18}$. The therapeutic regimen 2 NRTI +1 PI was most frequently associated with liver damage. Hepatotoxicity refers to increased cytoplasmic enzymes, especially alanine aminotransferase (ALT), and a slight increase in aspartate aminotransferase (AST) and bilirubin ${ }^{18}$. All ARVs may be hepatotoxic, either by mitochondrial toxicity or direct stress leading to steatosis $\mathrm{s}^{8,34}$. The factors that may contribute to its development include chronic hepatitis, underlying liver damage, alcoholism, and use of other hepatotoxic drugs. The ITRN + 1 NNRTI scheme was mainly associated with damage to the renal system. HIV can cause direct damage to the kidneys, manifested by HIVassociated nephropathy (HIVAN) ${ }^{8}$. Some studies have linked certain ARVs, especially TDF and the PIs lopinavir/ritonavir, $\mathrm{ATV} / \mathrm{r}$, and indinavir, with reduced glomerular filtration rate and abnormalities in renal tubular function ${ }^{35}$.

Based on the data from outpatient follow-up, $25 \%(55 / 220)$ of HIV/AIDS patients presented coinfections, the highest incidence being syphilis $(40 \%, 22 / 55)$. The epidemiological association between HIV and syphilis has been significant and was reported in many studies ${ }^{36,37}$. Syphilis is the most prevalent coinfection in people living with HIV/AIDS, and HIV/AIDS patients coinfected with syphilis may have a greater risk for neurological complications and may not respond to the recommended regimens. Immuno-troubling alterations may also occur causing a decline in CD4 + T lymphocyte count and an elevation of HIV viral load ${ }^{38}$. Tuberculosis represented the second most frequent coinfection (15\%), which is one of the main causes of death among people living with HIV/AIDS, requiring the implementation of effective actions, such as treatment of latent tuberculosis infection, which is one of the disease control measures in HIV-positive patients ${ }^{39}$. Therefore, it should be pointed out that healthcare professionals need to prioritize the control of tuberculosis, and those who work in the specific program should pay attention to the need for HIV assessment in patients who are being followed up in the service.

The coinfection between HIV and hepatitis B is explained by the common mode of transmission (mainly sexual contact). Chronic hepatitis B virus (HBV) infection occurs in 5\%-10\% of HIV-infected individuals, which is tenfold higher than that observed in the general population ${ }^{40}$. Epidemiological studies showed the association between the occurrence of $\mathrm{HIV} / \mathrm{HBV}$ in young adults and homosexual men. The mechanisms common to the transmission of HBV and HIV and the risk factors justify the high frequency of coinfection. However, our results demonstrated that the appearance of coinfections is not related to the level of adherence to ART.

In conclusion, this study evaluated the level of adherence of HIV/AIDS patients to ART at a reference center in Anápolis, State of Goiás, where a good adherence was observed among the study population. Adherence was significantly associated with higher CD4 + T lymphocyte count and lower viral load. The adherence to ART was associated with emergence of adverse effects, sexual orientation, and use of illicit drugs.

According to the literature, it is necessary to have a $90 \%$ adherence to ART to obtain undetectable viral load. However, 
in our study, only $50 \%$ of the population had strict adherence to ART, and $52 \%$ of the total sample had undetectable levels of viral load, showing that although adherence is classified as good, it is necessary to have strict adherence to reach the goals of ART.

Although our study was able to evaluate the adherence to ART of patients using TDF + 3TC + EFV, it is important to note that in Brazil, since February 2017, the initial preferential scheme for adults is now composed of TDF + 3TC + DTG. Therefore, further studies assessing adherence to ART using DTG need to be performed, since DTG has a lower number of adverse effects, the adherence to ART can be increased.

\section{Conflict of interest}

The authors declare that there is no conflict of interest.

\section{Financial support}

National Foundation for the Development of Private Higher Education FUNADESP 2016/2017.

\section{REFERENCES}

1. Shaw GM, Hunter E. HIV transmission. Cold Spring Harb Perspect Med. 2012;2(11):pii:a006965.

2. Girard MP, Osmanov S, Assossou OM, Kieny MP. Human immunodeficiency virus (HIV) immunopathogenesis and vaccine development: a review. Vaccine. 2011;29(37):6191-218.

3. Barbosa AN, Souza LR. Infecção pelo HIV/AIDS: uma doença crônica e tratável. Rev Racine. 2007;99(1):42-50.

4. Bartlett JA, Benoit SL, Johnson VA, Quinn JB, Sepulveda GE, Ehmann WC, et al.Lamivudine plus zidovudine compared with zalcitabine plus zidovudine in patients with HIV infection: a randomized, double-blind, placebo-controlled trial. Ann Intern Med. 1996;125(3):161-72.

5. Caetano JA. Immunologic aspects of HIV infection. Acta Med Port. $1991 ; 4(1) 52-8$.

6. Ministério da Saúde (MS). Boletim Epidemiológico 2016. Brasília: MS; 2016. Atualizadoem 8 demarço de 2016; citado em 5 de novembro de 2017. Disponível em:http://www.aids.gov.br/pt-br/ pub/2016/boletim-epidemiologico-de-aids-2016.

7. Ministério da Saúde (MS). Sistema de Informação de Agravos de Notificação 2015.Brasília: MS;2015. Atualizado em 8 de março de 2016; citado em 5 de novembro de 2017. Disponível em: http://http:// www2.datasus.gov.br/DATASUS/index.php?area $=0203 \&$ id $=6930$ $\& \mathrm{VObj}=$ http://www2.aids.gov.br/cgi/deftohtm.exe?tabnet/

8. Montaner JSG, Lima VD, Harrigan PR, Lourenço L, Yip B, Nosyk $\mathrm{B}$, et al. Expansion of HAART coverage is associated with sustained decreases in HIV/AIDS morbidity, mortality and HIV transmission: the 'HIV Treatment as Prevention' experience in a Canadian setting. PLoS One. 2014;9(2):e87872.

9. Arts EJ, Hazuda DJ. HIV-1 antiretroviral drug therapy. Cold Spring Harb Perspect Med. 2012;2(4):a007161.

10. Ministério da Saúde (MS). Protocolo clínico e diretrizes terapêuticas para manejo da infecção pelo HIV em adultos. Brasília: MS; 2013. Atualizado em 3 de outubro de 2013; citado em 5 de novembro de 2017. Disponível em: http://http://www.aids.gov.br/pt-br/pub/2013/ protocolo-clinico-e-diretrizes-terapeuticas-para-manejo-dainfeccao-pelo-hiv-em-adultos
11. World Health Organization (WHO). Global update on HIV treatment 2013: results, impact and opportunities. Geneve: WHO; 2013. 27p. Updated 2017 september 27; cited 2017 Nov 5. Available from:http:// www.who.int/hiv/events/2013/1_weiler_report_ias_v5.pdf

12. Ibrahim Y, Sutan R, Latif KBA, Al-Abed AAA, Amara A, Adam I. Poor adherence to antiretroviral therapy and associated factors among people living with HIV in Omdurman City, Sudan. Malaysian J Public Heal Med. 2014;14(1):90-101.

13. Achappa B, Madi D, Bhaskaran U, Ramapuram JT, Rao S, Mahalingam S. Adherence to antiretroviral therapy among people living with HIV. N Am J Med Sci. 2013;5(3):220-3.

14. Lencha B. Adherence to antiretroviral therapy and associated factors among people living with HIV/AIDS at Gobba Hospital, Southeast Ethiopia: an institutional based study. Qual Prim Care. 2015;23(6):336-41.

15. Brenchley JM, Schacker TW, Ruff LE, Price DA, Taylor JH, Beilman GJ, et al. CD4+ T cell depletion during all stages of HIV disease occurs predominantly in the gastrointestinal tract. J Exp Med. 2004;200(6):749-59.

16. Reda AA, Biadgilign S. Determinants of adherence to antiretroviral therapy among HIV-infected patients in Africa. AIDS Res Treat. 2012;2012:8.

17. Daniel A, Veiga EV. Fatores que interferem na adesão terapêutica medicamentosa em hipertensos. Einstein. 2013;11(3):331-7.

18. Chu C, Pollock LC, Selwyn PA. HIV-associated complications: a systems-based approach. Am Fam Physician. 2017;96(3):161-9.

19. Silva RAR, Nelson ARC, Duarte FHS, Prado NCC, Holanda JRR, Costa DARS. Avaliação da adesão à terapia antirretroviral em pacientes com AIDS evaluation of adherence to antiretroviral therapy for AIDS patients. Rev Online Pesqui Cuid é Fundam. 2017;9(1):15-20.

20. Galvão MTG, Soares LL, Pedrosa SC, Fiuza MLT, Lemos LA. Qualidade de vida e adesão à medicação antirretroviral em pessoas com HIV. Acta Paul Enferm. 2015;28(1);48-53.

21. Remor E, Milner-Moskovics J, Preussler G. Adaptação brasileira do'Cuestionario para la Evaluación de la Adhesión al Tratamiento Antiretroviral'. Rev Saude Publica. 2007;41(5):685-94.

22. Fiuza MLT, Lopes EM, Alexandre HO, Dantas PB, Galvão MTG, Pinheiro AKB. Adherence to antiretroviral treatment: comprehensive care based on the care model for chronic conditions. Esc Anna Nery Rev Enferm. 2013;17(4):740-8.

23. Oliveira LQ, Campesatto EA. Fatores que levam a não adesão dos pacientes em tratamento com antirretrovirais. Arq Ciênc Saúde UNIPAR. 2014;16(2):79-84.

24. Kamarulzaman A, Altice FL. The challenges in managing HIV in people who use drugs. Curr Opin Infect Dis. 2015;28(1):10-6.

25. Fernandes JRM, Acurcio FA, Campos LN, Guimarães MDC. Início da terapia anti-retroviral em estágio avançado de imunodeficiência entre indivíduos portadores de HIV/AIDS em Belo Horizonte, Minas Gerais, Brasil. Cad Saúde Pública. 2009;25(6):1369-80.

26. Altice FL, Kamarulzaman A, Soriano VV, Schechter M, Friedland GH. Treatment of medical, psychiatric, and substance-use comorbidities in people infected with HIV who use drugs. Lancet. 2010;376(9738):367-87.

27. Thompson MA, Mugavero MJ, Amico KR,Cargill VA,Chang LW, Gross R, et al. Guidelines for improving entry into and retention in care and antiretroviral adherence for persons with HIV: evidencebased recommendations from an International Association of Physicians in AIDS Care panel. Ann Intern Med. 2012;156(11): 817-33. 
28. Seth KC, Tamar G. Stress and poverty predictors of treatment adherence among people with low-literacy living with HIV/AIDS. Psychosom Med. 2010;72(8):810-6.

29. Silva JAG, Dourado MIC, Brito AM, Silva CAL. Fatores associados à não adesão aos antirretrovirais em adultos com AIDS nos seis primeiros meses da terapia em Salvador, Bahia, Brasil. Cad Saúde Pública. 2015;31(6):1188-98.

30. Remien RH, Bastos FI, Terto Jr V, Raxach JC, Pinto RM, Parker RG, et al. Adherence to antiretroviral therapy in a context of universal access, in Rio de Janeiro, Brazil. AIDS Care. 2007;19(6):740-8.

31. Remien RH, Dolezal C, Wagner GJ, Goggin K, Wilson IB, Gross $\mathrm{R}$, et al. The Association between Poor antiretroviral adherence and unsafe sex: differences by gender and sexual orientation and implications for scale-up of treatment as prevention. AIDS Behav. 2014;18(8):1541-7.

32. Foresto JS, Melo ES, Costa CRB, Antonini M, Gir E, Reis RK. Adesão à terapêutica antirretroviral de pessoas vivendo com HIV/ aids em um município do interior paulista. Rev Gaúcha Enferm. 2017;38(1):e63158.

33. Colombrini MRC, Lopes MHBM, Figueiredo RM. Adesão à terapia antiretroviral para HIV/AIDS. Rev Esc Enferm USP. 2006;40(4):576-81.
34. Araújo PD, Ehrhardt A. Avaliação do dano hepático em pacientes HIV positivo sob terapia antirretroviral no município de Carazinho/ RS. Saúde e Desenvolv. Hum. 2015;3(2):45-54.

35. Neto LFSP, Braga AC, Rocha JA, Vieira NFR, Miranda AE. Risk factors related to renal disorders in HIV-1 infected patients. Rev Soc Bras Med Trop. 2011;44(1):30-4.

36. Porro AM, Yoshioka MCN. Manifestações dermatológicas da infecção pelo HIV dermatologic manifestations of HIV infection. An Bras Dermatol. 2000;75(6):665-91.

37. Rodrigues EHG, Abath FGC. Doenças sexualmente transmissíveis em pacientes infectados com HIV/AIDS no Estado de Pernambuco, Brasil. Rev Soc Bras Med Trop. 2000;33(1):47-52.

38. Signorini DJHP, Monteiro MCM, Sá CAM, Sion FS, Leião Neto HG, Lima DP, et al. Prevalência da co-infecção HIV-sífilis em um hospital universitário da cidade do Rio de Janeiro no ano de 2005. Rev Soc Bras Med Trop. 2007;40(3):282-5.

39. Pawlowski A, Jansson M, Sköld M, Rottenberg ME, Källenius G. Tuberculosis and HIV co-infection. PLoS Pathog. 2012;8(2):e1002464.

40. Alter MJ. Epidemiology of viral hepatitis and HIV co-infection. J Hepatol. 2006;44(1):S6-S9. 